then if the rhinologist thinks there is plenty of room the operation should not be undertaken. It is important that is much mucous surface should remain in the nose as possible.

Dr. M. II. Fletcher, Cincinnati: In my own mind there is a question as to the solidity of the tissues when pressure is put on them. A suture, particularly of the skull, is particularly strong in its indentation. Is it always sure that division will oceur in the suture between those two bones and divide in the nose? Have any of you had any experirnce in laving separation at any other place than where you desired? It is impossible for us to see the thickness of the bone. I can conceive of $n$ case of very henry bones, in which there would not be separation in the proper place. Have any of you had any such experience? I should be glad to have any light on the question whether or not a separation at any other place than the suture would have a good or a bad result. Separation must come on one side of the septum or the other, must it not?

Dr. G. V. I. Brown, Milwaukee, Wis.: No, the ideal condition is separation between the central incisors. In view of the fact that the premaxilla is completely divided from other divisions of the superior maxilla in early life, it is curious that ossification becomes so complete on each side, and the median suture so marked. There is no longer a question as to where and how the maxilla separate. One of the questions evidently applies to those cases in which the suture is dove. tailed. My own opinion is that under such conditions the little interlocking portions of the suture are fractured.

In sonie few instances we have not had the outward and visible sign of maxillary division, which of course is indicated by separation of the incisors. In those cases we have usually lad good results also, but they were not such unusual types as Dr. Dean's patient. Sometimes I think that the premaxilla does not always unite in exactly the same way, because the separation occasionally appears between the central and lat. eral instead of between the two centrals. This ultimately readjusts itself, because an increase on one side gives more freedom for the septum to adjust itself.

DR. I. W. Dean, Iowa City, Iowa: I do not like to theori\%e in this matter, so far as changes in the nose are concerned. It has not been worked out completely, and I am afraid Dr. Brown and I would not agree as to how we get straightening of the septum after widening the arch. Work is being done, and a year from now it will be more definitely decided. I think this patient is going to have more breathing-space a year from now than she has at present. When I saw this patient after tlic first widening had been done, I could put a lead-pencil in between the incisors in front. I lastily wrote to Dr. Brown and got a letter from lim that he was ready to have these teeth brought together. This was done very nicely. We have widened the arches of skulls of subjects over 40 years of age. They have all opened along the median line.

\section{AN APPARATUS FOR SUPPORTING AND HOLD- ING THE HEAD AND SHOULDERS IN CEREBELLAR AND HIGH SPINAL OPERATIONS}

\section{HOMER B. SMITH, M.D.} FARGO, N. D.

The difficulties attending suboccipital and high spinal operations are largely due to the depth of the cerebellum and cord. Access to these parts is not easy on account of the difficulty of holding the patient's head and shoulders in a position that will allow a fixed field of operation, and at the same time not interfere with the patient's respiration and the administration of the anesthetic. This is especially true in trephining over the cerebellum with the patient in the prone position.

I devised the apparatus here described to obviate these difficulties. I first demonstrated its usefulness at the Boston Children's Hospital in an operation for cerebellar tumor. The satisfactory use to which this simple apparatus has been put in the past two years by various Boston surgeons, both in operntions for cerebellar exploration and cervical laminectomy, leads me to believe that as an aid in these operations the apparatus is worliny of mention.

\section{DLSCRIP'TION}

Figure 1 gives details of the head support. The apparatus consists of a base (liig. 1), an extension (Fig. 2), a head support (Fig. 3), and two shoulder supports (Fig. 4).

The buse (Fig. 1) is an oak plank, 17 by 8 by $1 \frac{1}{4}$ inches. A semicireular piece, 8 inches in diameter, is cut out in front. There are two one-half inch holes, bored through the width of the plank 10 inches apart $(a, a)$. These are to accommodate the extension. There are two set-screws, one at either corner in front (b, b), to receive the shoulder supports.
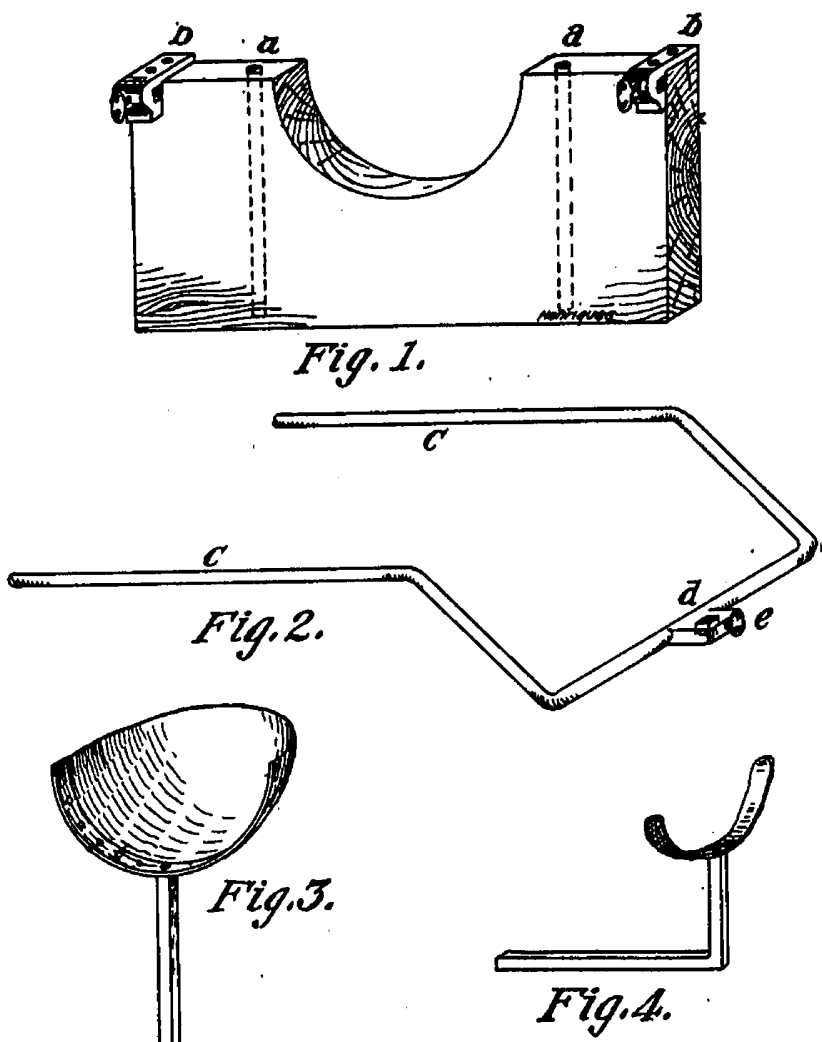

Figs. 1 to 4.-Detnlls of head support. Fig. 1 , base; Fig. 2 , extension; Flg. 3 , head support Fig. 4, slioulder support.

The extension (Fig, 2) is a three-eighths-inch iron rod, 48 inches long, so bent as to form two horizontal arms 18 inclies long (c, c), and a transverse rod (d) 10 inches long. The horizontal arms are bent downward at an angle of 45 degrees 13 inches from the ends. At the center of the transverse rod is a set-screw (e) to receive the head support.

The head support (Fig. 3) is a three-eighths-inch square iron rod 12 inches long, to one end of which is attached a semicircular piece of iron 7 inches in diameter and one-half inch wide. 'To this iron is riveted a heavy piece of mill-board which has been molded to make a quarter sphere.

The shoulder supports (Fig. 4), two in number, are three eighths-inch square iron rods $101 / 2$ inches long, and bent at ;ight angles 7 inches from the ends. To the short or upright arms are attached semicircular pieces of iron one-half incb wide and 4 inches in diameter. 
In use the hesid piece is corered with a sterile towel and the shoulder pieces are padded and bandaged. 'The apparatus is attached to the ordinary woolen operating table by two iron clanns.

'The head piece, extension and shoulder pieces permit wide adjustment. The hend of the patient can be raised, lowered, extended or flexed, and the shonlder pieces can be adjusted laterally to conform to the width of the patient's shoulders.

The illustration (Fig. 5) shows the apparatus complete. The diagram (Fig. (6) shows the vosition of a patient for operation.

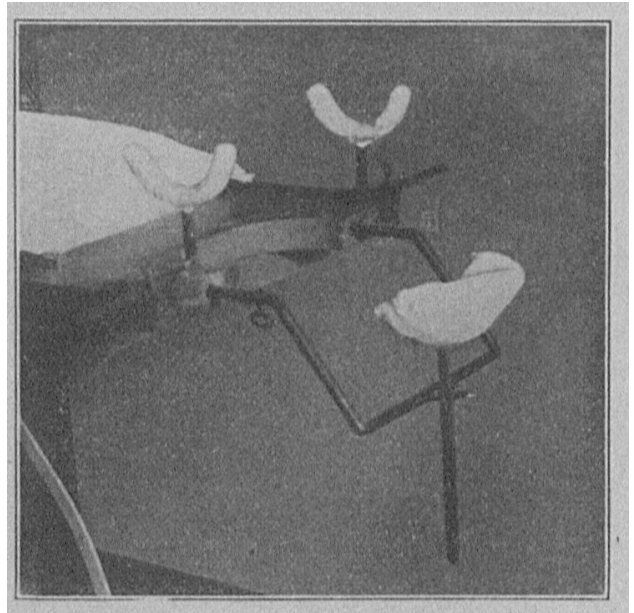

Fig. 8.-Apparatus complete.

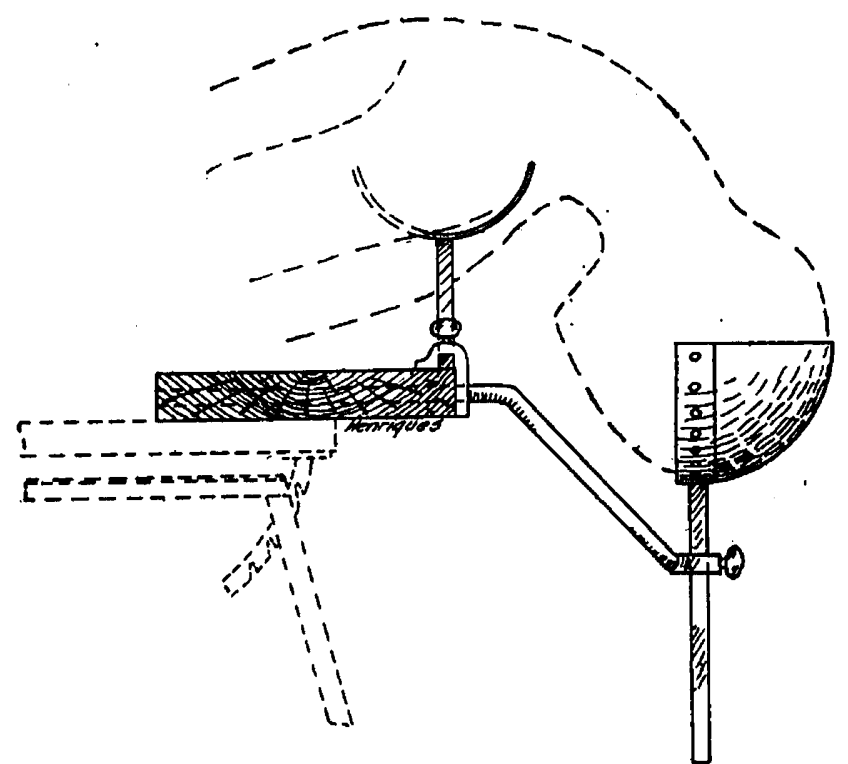

| Fig. 6.-Dlagram showing position of patlent during operation.

TILE ADVANTAGIS OH THE APPARATUS

The head of the patient is held in such a position as to afford a firm, immovable base against which to work.

'The patient's ehest is supported, allowing free respiratory movements.

The anesthetist is relieved of trying to do two things at once, namely, to hold the patient's head and give the anesthetic.

The apparatus is simple, has a wide range of adjustability and is cheap. It could be made lighter and could be more beautifully finished, thereby adding to its cost without in any great degree increasing its efficiency.

6.20 Front Street.
EN'TEROPTOSIS, WITH SPECIAI REFERENCE 'TO I'TS E'TIOLOGY AND DEVELOPMENT'

AND REMARKS ON TIIE RESULTS OF EXAMINATION OF FOUlR IIUNDRED WOMEN WITH REFERENCE TO THIS CONDITION *

RICHARD 1R. SMITH, M.D. GHAND RAPLS, MUCH.

The literature dealing with enteroptosis is a most roluminous one and I shall attempt nothing but a brief review of it. 'The subject is so unusually complex and presents so many difierent phases that it has led to much theoretical discussion, much of which has proven to be of little value. Our real advance and the best papers have come from those who have based their opinions on actual observations.

To Glénard, ${ }^{1}$ who in 1885 published his paper which to-day is a classic, belongs the credit of calling the attention of the profession to the existence of this condition. Glénard believed that the whole trouble came from a sinking of the hepatic flexure of the colon. From this conception he built a most elaborate theory, which wo know to-day has but little on which to stand. Glénard,

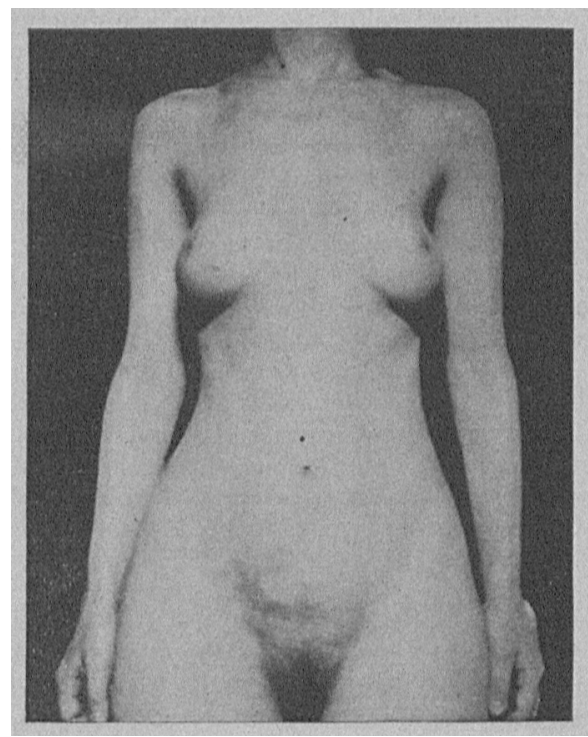

Fig. 1.-Typical enteroptotic figure. Fairly well-nourished. Musculal' sufficleney poor. 'Thortax depth 17 em., width 17.5) (!), Index 94.5 (!), belght $153 \mathrm{~cm}$, (5 f.t.), welght 94 lbs. Jight kldney palpable; lower pole of stomach below umbliteus (gas). Pain in r.lght slde, well-marked nourastlunia. Note small slze of thorax as compared with pelvis; small, long waist.

however, recognized the type of individunl in which enteroptosis was found and his description of it remains a classical one.

For five vears after this the discussion remained confined to the French literuture. In 1890, however, Ewald, ${ }^{2}$ in a thoughtful and conservative article. brought the matter before the German profession. He gave Glénard credit for his discovery,' but 'riticized many of his conclusions.

Stiller, ${ }^{3}$ in 1896, pointed out the hereditary character of the condition and elaborated his floating tenth rib

- Read In the Section on Obstetrice and Diseases of Women of the Amertean Medienl Assoclation, at the Sixty-first Annual Sesslon, held at St. Louls, June, 1910

1. Glenard: Application de ln methode nuturelle a l'nnalyse de lit dyspepsle nerveuse: détermination d'une espece, Iyon med., 1885, xlvili, 4ti!.

2. Ewald, C. A.: Ueber Enteroptose und Wnndernlere, Berl. klin., Welnschr, 1800, xxvl, 277, 304.

3. StIller, I3, : Ueber Enteroptose im Lichte eines neuen Stigma Nourasthenicum, A leh. e. Verdauungskr., 1806, $11,285$. 